\title{
A Model of the Configuration Process of HR Systems within Multinational Subsidiaries in Indonesia
}

\author{
Neil Semuel Rupidara \\ Department of Management, Faculty of Economics and Business, Universitas Kristen Satya Wacana \\ Jl. Diponegoro 52-60 Salatiga 50711, Indonesia
}

\begin{tabular}{l} 
A R T I C L E I N F O \\
\hline Keywords: \\
Configuration, \\
Empirical Model, \\
HR Systems; Indonesia, Institutional \\
Theory \\
Kata Kunci: \\
Konfigurasi, \\
Model Empiris, \\
Sistem HR, \\
Indonesia, \\
Teori institusional
\end{tabular}

Corresponding author:

neil.rupidara@uksw.edu
A B S T R A C T

This article develops an empirical model of the process through which human resource management (henceforth HR) systems within subsidiaries of multinational companies (MNCs) are constructed. It extends current models that had previously been developed. It is a second-order analysis that integrates research findings that had been previously published along with unpublished materials from the same research project. The research project applied different qualitative methods in data collection. Complementing a previous conceptual macro model of the configuration process of HR systems, this article adds on a micro-empirical model of the process. The model proposes that the adoption and enactment of new HR ideas that make up HR systems is initiated by the reconceptualization of corporate identity and facilitated by the connectivity of relevant HR actors that enables the flows of ideas from the outside into the firms. Five research propositions are finally proposed to be tested as a contribution for future research.

SARI PATI

Artikel ini mengembangkan model empiris sebuah proses melalui mana sistem manajemen sumber daya manusia (selanjutnya disebut SDM) dari anak-anak perusahaan multinasional (MNC) dibangun. Ini memperluas model yang sekarang, yang sebelumnya telah dikembangkan. Sebuah analisis orde kedua yang mengintegrasikan temuan penelitian yang sebelumnya telah diterbitkan bersama dengan bahan sama yang tidak dipublikasikan dari proyek penelitian. Proyek penelitian ini menggunakan metode kualitatif yang beragam dalam pengumpulan data. Melengkapi konsep sebelumnya model makro dari proses konfigurasi sistem SDM, artikel ini menambah model proses mikro-empiris. Model ini mengusulkan bahwa adopsi dan pemberlakuan ide-ide SDM baru yang membentuk sistem SDM diinisiasi oleh rekonseptualisasi identitas perusahaan dan difasilitasi oleh konektivitas aktor SDM terkait yang memungkinkan aliran ide dari luar ke internal perusahaan. Lima proposisi penelitian akhirnya diusulkan untuk diuji sebagai kontribusi untuk penelitian ke depan. 


\section{INTRODUCTION}

Despite the domination of content-oriented quantitative research, HR researchers have paid an increasing attention to understanding how HR systems are developed and work (e.g. Monks et al. 2013; Rupidara, 2018). This article focuses its attention on modelling the complex and dynamic process of configuring HR systems within firms that receives little attention. Such an understanding is lacking in the specific context of multinational subsidiaries that contains a complexity of push and pull factors in decision making process of HR systems development, particularly from developing country perspective. The process includes changes to the systems across time.

The configurational perspective has been used in explaining HR systems or bundle of practices (e.g. Delery \& Doty, 1996) and may thus be useful to understand their configuration process. This perspective emphasizes the importance of building HRM as an integrated and aligned system, internally and externally. Arguments and evidence for system perspective have also been well developed in strategic HRM and related literature (e.g. Arthur 1994; Arthur \& Boyles 2007; Kepes \& Delery 2007). Relating the perspective to the resource-based view of the firm (RBV) that pursues the fulfilment of criteria such as rareness and imperfect imitability in order to allow HR system to effectively contribute to sustained competitiveness of firms (e.g. Barney 1991; Boxall 1996; Wright et al. 1994), the process can be understood as a conscious, rational effort in developing distinctive features or elements of aligned HR system.

Research in organization studies have however shown also that organizations are subject to isomorphic forces (DiMaggio \& Powell 1983). Thus despite the rational intentions in establishing uniqueness, firms are simultaneously getting similar in many organizational attributes, including HR practices (Rupidara \& Darby, 2017). The conflicting directions of intentional organizational strategic acts and their embeddedness in institutional realities therefore need to be understood properly and empirically in an attempt to develop an empirical model or theory of the configuration process.

The proposed model from this research is derived from a particular context of foreign multinational companies (MNCs) operating in Indonesia. Although it may contain limitations regarding characteristics of the context, the model is considered useful for researchers in developing a better understanding about the process. To proceed to the theorisation of the process based on empirical data from the research context, this article is aware of any differences of characteristics across institutional contexts. The model thus needs to be taken with care when anyone considers a cross-context transferability of the model.

To present its findings, this article is organised as follows. The subsequent section presents a brief theoretical view around the configuration process. The explanation of the methodological aspects of the research is then provided. Following that, empirical findings are presented along with the development of the model of the process and propositions for future research. Conclusions and recommendations are provided in the final section.

\section{Literature Review: Theorising the Configuration Process from the Indonesian Context}

Existing research argues for the importance of taking a configurational or system perspective in HRM (Arthur 1994; Boxall \& Steeneveld 1999; Delery \& Doty 1996; Kepes \& Delery 2007; Khatri 2000; Huselid 1995; MacDuffie 1995; Wright, McMahan, \& McWilliams 1994). This argument has been built upon growing research interests and findings in support of the strategic role of HRM in organisations and firms in general and MNCs in particular. The resource based view (RBV) (Barney 1991; Wright et al. 1994), a dominant theoretical perspective in strategic HRM (SHRM), argues that HRM, through its systems of operation, plays a critical role in improving firm performance and contributing to the competitive advantage of the firm. Several types 
of HR systems, such as high performance, high commitment, or high involvement work systems (Becker \& Huselid 1998; Edwards \& Wright 2001; Guthrie 2001; Den Hartog \& Verburg 2004; Huselid 1995; Pil \& MacDuffie 1996), have been identified as contributing to higher firm performance and thus support this argument although other research shows that low commitment/involvement practices can also lead to high performance (e.g. Lewin 2001; 2002). The systems (sometimes called a bundle of coherent practices) have become a theoretical orthodoxy in HRM and widely influenced HR practices in many organisations. Despite the increasing importance of taking a systems perspective, this article identifies the shortfall in detailed understanding about how the coherent systems come into existence and how they are reconfigured over time.

Understanding the process of configuring aligned HR systems is argued as important (Rupidara, 2018). The reason is, first, the better the systems are configured, the higher the probability of delivering HR activities that could enable human resources to increase firm performance (Huselid 1995). Second, it is not a simple process. Kepes and Delery (2007 p. 389) state that, "It is a very difficult task to actually design internally consistent HRM systems..." although they don't elaborate it but arguing that it is beyond the scope of their work. This lack of full knowledge of the process therefore needs to be addressed.

This article is related to and advances from a current development that has revealed some aspects of the dynamic nature of the configuration process of HR systems (e.g. Rupidara, 2018; Rupidara \& McGraw, 2011). Some mechanisms involved in the process, either at the field or firm level, have been identified particularly related to isomorphic behaviour of actors (see also Rupidara \& Darby, 2017). Other aspects involved in the process still however need to be identified and disclosed. In so doing, it is understood that any effort to capture the dynamic characteristics of continuing and complex processes, however, runs the risk of oversimplifying the rich nature of the processes and their interactions with various contingency variables. Some efforts might have been simplistic to any extent since integrated systems are understood as evolving over time and subject to change due to constant variations in the surrounding environments. This is parallel to the criticism of Chadwick and Cappelli (1999) on the overuse of generic typology of strategy in SHRM research that lacks the complex reality of strategies in actual practice. The lack of understanding about the dynamics of various HR processes, including the configuration of HR systems, has been acknowledged in RBV literature (e.g. Barney, Ketchen, \& Wright 2011; Foss 2011; Kraaijenbrink, Spender, \& Groen 2010).

With regard to the aim to model the configuration process of HR systems, Rupidara and McGraw (2011) have modelled the process conceptually. That model was developed based on their attempt to blend three theoretical lenses, namely the resource-based view, institutional theory, and political view of actors. The authors argue that such approach is important and helpful in dealing the complexity involved in the process. The model depicts multiple key actors and different institutional isomorphic mechanisms that interact each other in and across different levels of institutional settings that in turn driving HR managers within multinational subsidiaries into certain choices when they configure HR systems of their firms.

In taking up the different theoretical perspectives, particularly the institutional theory, in the effort to develop an empirical model the process inductively, this study is aware of how the contextual setting of the study may play a significant influence over the result (cf. Paauwe 2004 for context-bound view). The institutional contexts surrounding the Indonesia HR field and actors, whether it the national business system, employment regulative environment, or even the wider institutional settings, may have influences and facilitate the travel and adoption of HR ideas from external into the firm contexts. By 
acknowledging the potential of finding similarities and differences of HR ideas that are adopted and practiced by multinational subsidiaries in Indonesia, the study is considered bringing the characteristics of Indonesia as a developing country into the constructed model resulting from this research. In so doing this study considers it as a contribution from developing country perspectives that is still deficient in the existing body of HR knowledge (cf. Napier \& Vu 1998; Ozbilgin 2004). Existing knowledge has been mainly constructed from the developed economic settings, e.g., in the UK and other European countries, Australia, Singapore, Korea, and particularly the US and Japanese (Ferner 1997). This means that the perspectives from the developed economies have been dominating the diffusion of HR ideas across the world although there is also a growing impetus to do research in countries such as China (Bjorkman \& Lu 2001; Bjorkman \& Xiucheng 2002; Li 2003; Farley et al. 2004) and India (Paul \& Anantharaman 2003). Research in and from developing countries is, however, still lagging behind despite the fact that it could offer alternative perspectives in understanding $\mathrm{HR}$ issues in general and the process of configuring HR systems in particular. The opportunity for this research to offer a perspective from the context the developing and transitional economy of Indonesia is thus expected add to the existing body of knowledge in the field of SIHRM.

\section{METHODOLOGY}

It has to be clearly understood that this article contains a second-order analysis of research findings based on the first-order analysis of empirical data conducted earlier. A few publications and unpublished materials were the outputs of the first-order analysis, which contain quotations from narrative conversations between the researcher and key informants from participant and other organizations involved in this research. As a secondorder analysis this article does not include direct quotation of the empirical data. Regardless that nature, it is considered proper to elaborate on main methodological aspects of the research for potential examination of it.

\section{Research Design}

The research that the article is based was guided by a broad research question (cf. Collis \& Hussey 2009; Jovchelovitch \& Bauer 2000), "How have HR actors within foreign multinational subsidiaries in Indonesia configured the HR systems of their companies? As a result of framing the question in that way, the research was designed as a naturalistic investigation (cf. Erlandson, Harris, Skipper, \& Allen 1993) into the processes of configuring HR systems within multinational subsidiaries. The researcher entered the natural setting of work experiences of HR actors in the field and invited them to generate narratives of the process based on their experiences in developing and changing systems.

This is a qualitative research situated within an interpretive-constructivist paradigm (Burrel \& Morgan 1977; Charmaz 2006; Denzin \& Lincoln 2005; Schwandt 1994). The research valued interactions of HR actors in the field and between the actors and the researcher as media of meaning constructions. This was particularly exercised through narrative interview format taken to allow rich, open-ended conversations taking place. The research was directed to build its findings through inductive reinterpretation of fieldwork data using a modified grounded analysis.

The research was explorative in nature. It took multilevel, multi-actor approach (cf. Mäkelä et al. 2014; Rupidara \& McGraw 2011). It tried to understand the connectivities of HR actors at firm level and relevant external actors within the field of HR in Indonesia. At the field level, the study observed communities of Indonesian HR actors, including HR managers, consultants and academics, using different primary and secondary methods.

At firm level, the study took the format of in-depth case studies (Eisenhardt 1989; Mabry 2009; Stake 1994; Stark \& Torrance 2008; Yin 1989) in order to capture and reveal deeper understanding of the process of configuring HR systems. It was designed to be experiential (cf. Erlandson, Harris, Skipper, \& 
Allen 1993; Mabry2009). The researcher conducted fieldwork consisting of work-in experiences within a set of companies for a period of two weeks, in order to collect data and acquire a general sense about the nature of work of the actors within the case firms. Such a design is appropriate for a phenomenological study (Dahlberg et al. 2001). The work-in period was first designed for 1-2 months but adjusted into two weeks as it to agreement with the firms.

The criteria for selecting case companies emerged naturally as the first company, CoInsure, signalled its participation. A quick investigation into the characteristics of the firm was conducted to generate guiding principles (e.g. recent ownership change, from local to multinational affiliated) for selecting other companies. The emerging criteria were applied and continued to develop when the opportunity arrived to involve the second company, CoCement. The criteria were settled and thus used to decide the participation of the third company, CoTobacco. The main criteria applied were, first, that the case companies were joint-ventures with dominant ownership by foreign MNCs and second, that these MNCs were formerly Indonesian companies so that experienced a shifting ownership. Three MNCs and an additional comparing case of an Indonesian state organisation were participated in the study (Table 1).

Table 1. The Characteristics of the Case Organisations

\section{Data Collection}

Data collection comprises of three phases. The first was the study of general trends in the Indonesian HRM field, as part of the Indonesian institutional context that was considered important for the study. Different methods of data collection were used in this phase, namely observations into eight electronic mailing lists of Indonesian HR communities, email interviews, and secondary data collection. Email interviews were conducted with six HR professionals, two of whom turned out to be HR consultants, from different companies. Although the number is small, the data was informative and was analysed in combination with other data. Secondary data were obtained, mostly from internet sources, of magazines, newsletters, personal blogs, and previous research reports. These data were treated carefully, for example by cross-referencing whenever possible. Interview data was later added with face-to-face narrative interviews particularly with HR consultants and academics during the fieldwork in the third phase. Data from case studies also informed the analysis.

In the second phase, the study focused on analysing changes in the Indonesian regulatory environment, more specifically within its industrial relations (IR) system. The study formerly focused on developments after the 1997 economic crisis in Indonesia that significantly impacted the IR system. It was later extended to cover a longer evolution

\begin{tabular}{lllll}
\hline & $\begin{array}{l}\text { MNC A: } \\
\text { CoCement }\end{array}$ & MNC B: CoInsure & MNC C: CoTobacco & $\begin{array}{l}\text { Indonesian Public } \\
\text { Institution D: InMonebank }\end{array}$ \\
\hline Industry & Cement & Insurance & FMCG/Tobacco & $\begin{array}{l}\text { Banking and Monetary } \\
\text { Policy and Regulation }\end{array}$ \\
\hline $\begin{array}{l}\text { Current Dominant } \\
\begin{array}{l}\text { Parent Nationality (\% } \\
\text { share, approx.) }\end{array}\end{array}$ & German (65.19) & Australia (80) & USA (98) & Indonesia \\
\hline $\begin{array}{l}\text { Former Parent } \\
\text { Nationality }\end{array}$ & Indonesia & $\begin{array}{l}\text { Indonesia and its } \\
\text { foreign partners }\end{array}$ & Indonesia & Indonesia \\
\hline Acquisition Year & 2001 & 2007 & 2005 & -- \\
\hline No. of Employees & $5,000 \mathrm{~s}$ & $\begin{array}{l}300 \mathrm{~s}+5,000 \mathrm{~s} \\
\text { agents }\end{array}$ & $30,000 \mathrm{~s}$ & $6,000 \mathrm{~s}$ \\
\hline
\end{tabular}

Note: The same table is also used in Rupidara (2018) 
of the system. This impacted on data collection. Data on post-crisis changes were acquired through interviews with seven IR actors, who were involved in one or more related events during the transition. Relevant reports issued by International Labour Organisation (ILO), labour non-governmental organisations (NGOs), and research institutes, online written documents from organisational or personal blogs, newspapers, and previous scientific publications were also used. Data on past events were gathered from previous scientific publications and other reports, and secondary data from the Dept. of Manpower and Transmigration was also used to support the analysis.

The third phase focused on the case studies conducted at three MNCs and one public organisation and analysed the configuration of HR systems. Data for this study were collected during fieldwork in Jakarta that lasted for about 3 months Work-in periods within each case organisation consisted of eight to ten working days and eight hours a day, on average. The researcher was provided with a work-space next to or within the HR department of each organisation.

During this phase, data were mainly collected through interviews with $34 \mathrm{HR}$ managers from the four case organisations. A line manager, who heavily involved in a strategic redirection program on company (CoCement) that impacted on changes in the company's HR systems, was also interviewed. The HR interviewees were chosen by the organisations according to their roles in managing central elements of HR systems within each organisation. No employee was involved in these interviews, as the research focus was on HR actors who involved in configuration processes although informal talks also conducted with employees. All interviews were scheduled by a liaison officer within each organisation, in agreement with the researcher.

All interviews had an in-depth, open ended, narrative interview format (Chase 2005; Czarniawska 2004;
Elliott 2005; Flick 2006; Hopf 2004; Jovchelovitch \& Bauer 2000; Riessman 2008). Narrative interviews refer to a way of acquiring data or information about previous events or experiences, or knowledge about them, in a story-telling format, which not only tells about the events themselves but also reflects the insertion of meanings by the storyteller (cf. Jovchelovitch \& Bauer 2000). These interviews loosely followed a structure suggested by Jovchelovitch and Bauer (2000). Each interview started with a brief explanation about the topic and objective of the research, and the interview approach was explained in order to provide broad guidelines for all the interviewees.

The interviewees were then asked to briefly explain their role and responsibilities within their organisation before they started to tell their stories about the process of configuring HR systems within their firm. Interviewees were asked to particularly comment on the element of the systems they were responsible for. In investigating the configuration process, the interviews were guided by an open question, 'What has happened here?' Questions for further elaboration were asked after the main segment of the story-telling ended, even if only a short story had been provided by the interviewee. The intention was to allow interviewees the opportunity to recall and mobilise their memories by developing their historical narratives more freely and naturally, rather than the researcher trying to frame their thinking with a structured or semistructured interview approach. This characteristic is considered to be in accordance with both the natural realist approach that seeks rich descriptions and the constructivist approach that views the process as one of constructing meanings (Elliot 2005).

Interviews lasted for one to two hours and were tape recorded, except for interviews at CoTobacco as it was formally prohibited by the firm. Most of the recordings were transcribed by the researcher. The transcripts were made verbatim and included capturing pauses, as well as any actions performed by 
the interviewees, or particular emphasis or specific voice tones used. These were recorded in order to catch the dynamic interactions and the emotional nuances expressed during the interviews. The researcher also took notes during all interviews.

Observations on daily working lives within the case organisations, particularly within the HR departments, also contributed to the main data set. Narrative documents were produced to record events captured by the researcher during each work-in period. Not only the events themselves that were recorded; meanings were also usually attached to them, based on the researcher's interpretation of events.

Documentary study was another method used in data collection. Both printed and electronic documents relevant to HR systems were recorded as electronic files or transcribed into research notes.

All the aforementioned shows important characteristics of this research that are the use multiple data-collection methods to multiple interviewees within one firm, as well as the period of time for observations into the organisations. Table 2 summarises data collecting activities. The characteristics allowed data triangulation to reduce distortions to some degree (Flick 2004).

\section{Data Analysis}

Consistent with the research approach, data were analysed within the interpretive- constructivist paradigm (Burrel \& Morgan 1977; Charmaz 2006; Denzin \& Lincoln 2005; Schwandt 1994). Two stages of data analysis were executed. First, data analysis was initiated after the first data had been collected and continued throughout the data collection process. This analysis was conducted to make sense of every piece of data at one point in time and the results were used to inform the next step. General themes were generated and refined to construct a more holistic understanding of the process of configuring HR systems. Although the intention of this process was to produce an accumulated understanding, the characteristic of this analytical process was more piecemeal than comprehensive. The comprehensive data analysis was conducted after all the fieldwork data had been collected. This is the second stage of data analysis.

The second stage of data analysis was conducted by employing different styles of analysis according to the different phases of study outlined previously. In the first phase of this study, data analysis was conducted prior to the fieldwork and this analysis was mainly explorative, seeking to find general characteristics of the Indonesian HRM field and major patterns of behaviour within firms in terms of HR practices. A general interpretation was conducted of the data available.

Data analysis in the second phase took a similar, general approach to the first in analysing the evolution of the Indonesian industrial relations systems. It was a more detailed process of analysis, however, finding and generating main categories from interviews and other data. It did not particularly use the same coding technique applied to the third phase of the research, which is elaborated in the following paragraph.

In the third phase, the case studies on configuration process, data analysis was conducted by employing grounded theory methodology (Birks \& Mills 2011; Charmaz 2006; Glaser 1978; Glaser \& Strauss 1977) and informed by the process of theorising from case studies (e.g. Eisenhardt 1989). The use of grounded theory in this research had been modified. This research did not apply a 'pure' grounded-theory style of analysis in developing categories based solely on data, but constantly involved literature review in the process of developing and elaborating themes generated from the coding process.

Because this was a continuing analysis, there were early results from the general analysis in the first stage that generated general themes and memos, or records of thoughts (Birks \& Mills 2011; Charmaz 2006). These results informed a more comprehen- 
sive data analysis stage that was conducted after the fieldwork data collection was completed. The analysis was done line by line of each interview transcript or by careful listening to interview recordings that had not been transcribed. In conducting coding process, NVivo was first used to structure the process. For the reason of convenience and speed, however, further analysis was conducted manually. This analysis was also supported by fieldwork narrative texts from observations and informal talks. The results of the process refined and reinforced the earlier analysis results and led to the development of more robust concepts and meanings.

The analysis then moved to understand and depict the patterns of relationships among the concepts. During these processes, memos, models or schematic relationships of the major concepts were developed and refined. The results were constantly evaluated based on data and also consulted to literature to reach the final state of analysis.

The overall analytical process is best described as iterative and multilayered in nature. Transcripts were read and recordings were listened to several times and were constantly compared with research notes taken during the fieldwork. The results of the analyses were re-read and related to relevant literature in order to achieve a satisfactory level of understanding and to reduce any possible bias in interpretation, despite the fact that subjectivities were part of the whole research process. This iterative process resulted in six conference papers that were later developed into the five articles that form the overall findings of this research. The contents of each articles are briefly summarised in the next section.

This current article integrates all research findings presented in the different articles and papers into one piece of cohesive work in order to build a unified model of the configuration process of $\mathrm{HR}$ systems as proposed by this research. Restating the aforementioned, it thus contains no direct quotations of empirical data, which they may be found in previous publications and unpublished papers.

\section{Results and Discussions}

This section presents research findings extracted from five early reports where the findings were lengthy documented and they were reconstructed into a holistic model for theorising the process. As previously mentioned the research addresses a broad question asking how actors within multinational subsidiaries in Indonesia configure HR systems. The question was translated into a more operational question to guide the field interviews, asking "what has happened here?" HR actors either within the case multinational subsidiaries or the comparison case of an Indonesian public organisation were invited to provide narrative accounts in delivering their views about the process of configuring HR systems, particularly regarding elements of the systems within their areas of responsibility.

\section{Reconstructing the Research Findings}

The research process contains an evolution of the research ideas. An early idea identified key elements of the process of configuring HR systems within the context of multinational subsidiaries. A theoretical model of the process was developed, arguing that managerial decisions taken by HR actors within firms should be understood within the context of influences that not only come from within a limited strategic environment of firms and from human rational capabilities in decision making, but are also significantly influenced by institutional factors and political processes (see Rupidara \& McGraw, 2011). This model was derived from three theoretical points of view, namely institutional, rational-choice, and micro-politics, and it was noted that each plays some roles in the process. It raised a concern over the dynamic relationships between actors, including their intentions, and institutions, including their logics and mechanisms. It developed a unique blended perspective and suggests how the different influences should be understood in the research context of the configuration of HR systems, 
particularly in relation to multinational subsidiaries.

The early result also identified three critical dimensions for accurately representing the process of configuring HR systems: a multilayered approach; interconnectivity between layers; and in-depth studies at the micro-firm level. These were argued to be significant in the configuration process although the model required further refinement and empirical verification. It provided a broad but fundamental viewpoint in answering the research question.

The second article from the study (see Rupidara \& McGraw, 2010) focused on the wider institutional environment in Indonesia that was considered influential in constraining or facilitating choices of action by HR actors, namely the regulative institutions, particularly labour laws and the industrial relations system. Because a regulatory environment has coercive power and mechanisms to enforce legal compliance by firms, including multinational subsidiaries, studying the transition of the Indonesian IR system was considered critical in understanding its viable effects on firms with regard to HR/IR policies and practices within firms, including multinational subsidiaries. This was considered important because the system underwent reforms since 1998 and have had significant impacts. Besides structural changes in a number of aspects of the IR system, behavioural aspects of and within firms were also affected. An example was the increasing use of outsourcing practices. This particular example showed how legal endorsement was effectively utilised by actors in the pursuit of their interests. In relation to the phenomenon of isomorphism among organisations in Indonesia as observed in this study, the report indicated that regulatory institutions can be an effective device in intensifying local isomorphism.

On the other hand, other evidence showed that there were sometimes unobserved behavioural phenomena that are taken-for-granted and keep elements of the institutions of the Indonesian IR system unchanged. These were argued to be deepseated in cognitive understandings maintained by institutional mechanisms and had profound influence on the behaviour of actors in resisting change.

Beyond the impacts on choices of action at firm level that the regulatory changes had have, the report also showed the interactions between actors and institutions, including institutional logics and mechanisms. This is very relevant for understanding the dynamic but sometimes hidden interactions between actors and institutions in the process of configuring HR systems. Another important dimension was the utilisation of historical perspective in studying institutional changes, an approach that is helpful in investigating and explaining a continuing process such as the configuration of HR systems.

The third article focuses on the wider institutional settings that surround and influence HRM systems within firms (see Rupidara \& Darby, 2017). Evidence was prevalent to come to a conclusion that isomorphic mechanisms played a role in the diffusion and adoption of similar HR policies and practices within and across firms. The Indonesian HRM was therefore categorised as highly isomorphic field. Empirical data from investigations in case organisations supported the claim. There was also strong evidence of how institutional effects had significantly influenced the functioning of the Indonesian HR field and particularly the configuration process of HR systems. This isomorphic phenomenon was identified as being related to the transitional nature of the HR field in Indonesia. Actors in the field were eager to seek more advanced, globalised ideas from the external environment. These invigorating institutionalised ideas were then diffused among the human actors or between organisations. This confirmed the critical role of institutions in managerial decision making processes through the diffusion and adoption of already legitimate and well-established ideas into organisations from wider institutional fields. 
The fourth articles presents critical evidence on the role of multiple-connectivities of actors in mimesis practices (see Rupidara, 2018). Various forms of connectivity linked different actors, both human and organisational, and institutional logics or ideas flew into and through the links. Both the multinational case firms, and the comparative case of the public organisation, were involved in these connectivities in one form or another. The connectivities were not only developed with peer-actors within the multinational firms but also with actors outside; in the wider field of HR in Indonesia, and also with actors abroad, as for example in the InMonebank case. The connectivities of actors were identified as an important element in the process of configuring HR systems by connecting the thinking and decision processes within firms with various sources of ideas.

Based on the findings, the study contended that connectivities or relationships among actors are a key response to the actual mechanisms of institutional isomorphism that are still lacking in institutional arguments as widely noted (Campbell, 2004; Meyer and Rowan (1977; Greenwood et al., 2008). The study showed that connectivities of actors can explain how isomorphic processes at an organisational field level are manifested in imitating acts at firm level and thus link the actions of actors to institutionalised rationalities or ideas that are diffused widely across institutional fields. Connectivities of actors are therefore a critical linking mechanism in further explaining the isomorphism mechanisms that have been so important in organisational studies in general and in SIHRM in particular.

The report showed three different lines of connectivity between the HR actors within organisations and their counterparts outside, either within the same multinational network or in consulting and academic domains. The different forms of connectivity are undoubtedly an ordinary phenomenon of everyday professional relations between actors in the HR field. Their disclosure as a linking mechanism is very important, particularly for this study, which investigates the sources of ideas and how HR systems within multinational subsidiaries have been configured.

The fifth report, which has not been published yet, looks deeper into the micro-processes that HR actors within firms deal with when they make decisions in the configuration of HR systems, particularly explaining the mimesis phenomenon in the process (see Rupidara 2011). In so doing, a framework was proposed for assessing the mimesis phenomenon. In explaining the drivers or logics of the adoption of external ideas, besides presenting evidence for rational choices, it built the case for the importance of the social identity of firms, particularly as perceived by HR actors of organisations. The linking of the identity of firms to the imitating behaviour of organisational actors was crucial in dissecting the phenomenon of mimesis into the actual behaviour of actors. In explaining the role of identity, it identified both the facilitating and resisting roles of identity in the adoption of external ideas into organisations in the process of configuring HR systems. The facilitating role of corporate identity was related to the self-categorisation of an organisation towards 'other' organisations that are considered as having better HR systems. This was called an aspirational identity. The 'new' self-identification was argued as driving a firm to imitate other firms, not necessarily the multinational headquarters, and to create similarities in elements of their HR systems, thus explaining how isomorphism occurs. This empirically-based explanation was important in theorising the configuration process of HR systems within firms, particularly within the multinational subsidiaries context, and more specifically from the perspective of MNC subsidiaries in Indonesia. On the other hand, corporate identity can be used to block incoming ideas from firms. This was argued as being related to competing identities, ideas, or logics held among actors within the firms.

Since the study also indicated that change of identity seemed to happen prior to the adoption of 
ideas from outside the organisations, it appeared that institutional mechanisms may play a role in facilitating the encounters of actors and new ideas. At any point of time in the encounters, cognitive processes on the actors' side might be stimulated and usually followed by adoption. Linking this back to what previously mentioned, it suggested that the encounter is possibly due to the different connectivities established by the actors and/or facilitated by institutions. Thus, although further evidence is needed to strengthen the idea, it was adequate enough to propose that the relationships between actors and their wider institutional contexts, through the facilitating role of corporate identity, are important in explaining changes inside organisation, particularly in the elements of HR systems through the on-going configuration process. These relationships are important contribution for the understanding of the configuration process in particular and may also for changes within organisations in general.

Based on the key empirical findings, this article now highlights a number of key issues in the process of configuration of HR systems within multinational subsidiaries. First, isomorphism is the central concept and mechanism in explaining the configuration process, particularly in the field of Indonesian HR. Both at the macro-institutional and micro-organisational level, there is clear evidence for isomorphism. Mimetic processes seem to be and are argued here in this research as a major mechanism in configuring process as ideas, through various cultural-cognitive processes, tend to penetrate all other domains and mechanisms. Consequently, mimesis is thus treated as a general phenomenon to describe how actors constantly represent institutionalised ideas within and across particular contexts through the adoption of similar element of HR systems by different organisations. This logically leads to a conceptual advancement of mimesis into becoming a root or fundamental concept (cf. Potolsky 2006) in itself like isomorphism. Mimesis used in this sense is distinguished from mimetic process as defined by DiMaggio and Powell (1983). If isomorphism describes the phenomenon of how organisations become similar to one another (DiMaggio \& Powell 1983), for example in the case of major elements of HR systems as this research has shown, the concept of mimesis then explains the way the phenomenon occurs, namely by imitating more legitimate ideas or models. An imitating act may involve power and pressure, also standardised or institutionalised norms or rules, and it may thus become coercive or normative. It may occur either voluntarily, driven by uncertainties, referred to as a mimetic process in the new institutionalism (DiMaggio \& Powell 1983), or it can simply be referred as a cultural-cognitive process or mechanism (Scott 2008).

In explaining mimesis and isomorphism, this research has shown that connectivity is a critical element. The combined narratives show that there will never be mimesis, and therefore isomorphism, if there is no connectivities among actors, between actors and institutions, and among institutions. Existing literature in organisational institutionalism shows that widely accepted institutional mechanisms, i.e., coercive, normative, and mimetic, have been used to describe the links between institutions, but they are understood as operating also through actors, and thus among actors. The concept of organisational field (DiMaggio \& Powell 1983) implicitly describes connectivities among the population or elements of a field. This research highlights connectivity as a more explicit element in understanding isomorphism within and across organisational fields. It also shows that at the micro level, actors often create links among themselves and these links later become channels for the flow of different institutionalised HR ideas.

With a constant flow of ideas, there can be many different and sometimes conflicting ideas diffused in the field, situating firms and their HR actors in a context that is full of competing ideas or pressures. Not all actors, however, experience the same level of pressure and each may have a different level of exposure to the ideas available within the field or 
within reach of the field. Unlike the advice of the rational choice perspective, actors may not always be easily choosing the best alternatives as there exist bounded rationality of the actors and institutional constraints. The study argues that the relational and psychological nature of the actors and the ideas is an important factor that leads to managerial choices, as explained by the concept of corporate social identity, or more specifically the aspirational identity of the firm. This variable was not anticipated at the outset of this study, but the empirical findings suggest that it plays a role. The study in fact adopts the idea although this particular finding needs further investigation and more evidence from other contexts in order to confirm the explanatory power of the variable.

The study identifies that there is a widening or greater ease of access to institutional fields. The case studies show that organisations can now reach far into various sources of ideas outside their immediate environment, whether that is outside the organisational boundaries of the MNCs or the geographical boundaries of Indonesia. The MNCs clearly have links to well established ideas within and through their multinational networks. The subsidiaries of MNCs and other local organisations, such as InMonebank, have access to other external pools of knowledge through channels such as consulting firms and also through overseas or outward mobility of their HR personnel. This shows that it is becoming more difficult to maintain the traditional view of concepts such as organisational field and local isomorphism. Similarly, it is becoming difficult to maintain a bipolar mode of thinking, such as the tension between headquarters and subsidiaries, as dominantly used in conceptual frameworks in SIHRM or Strategic International Management studies (e.g. Bartlett \& Ghoshal 1991, 2000; Taylor et al. 1996). As fields become more open and accessible, isomorphism can occur on a wider scale and at differing organisational levels.

This study greatly emphasises the role of institutional effects in the configuration process. HR actors in the field tried to refer to certain rationalities in making decisions to adopt external ideas in the configuration process, although the rationalities are to some extent constrained or shaped by institutionalised logics accepted in the wider institutional contexts. There is indicative evidence of the relevance of micro-political aspects in the process as different actors bring different, sometimes competing, ideas into the same organisational realms, and as the HR actors seek legitimacy from their counterparts. Further investigations are needed, however, in order to develop a full account of the dynamic and complex relationships of the different aspects in the configuration process, as previously clearly identified in early theoretical developments in this study.

\section{Modelling the Configuration of HR Systems within Multinational Subsidiaries}

As empirical evidence accumulated, the ideas informing the research were constantly revisited. As the research aims to theorise around the process of configuration of HR systems within multinational subsidiaries, it is now the time to revisit the theoretical model proposed by Rupidara and McGraw (2011). The construction of the model is considered proper as this research has chosen to develop the model by grounding it on data. In so doing, it should be noted that although the research has not been able to provide a complete picture of the continuing and complex process, inputs from empirical findings have been very significant in rebuilding the earlier model. The empirical findings do not rule out the theoretical model but rather enrich and re-contextualise it. The model is divided into two. First, a macro model to depict the phenomenon in the HR field, and second, a micro process model to depict events dealt with by HR actors within multinational subsidiaries.

The macro model of the configuration process of HR systems within multinational subsidiaries (Rupidara and McGraw 2011) shows that institutional isomorphism, through its mimetic, coercive, and normative mechanisms, is a key influence on the 
process. Empirical findings from the research, both at the field and firm levels, confirm the highly isomorphic nature of the HR field particularly in Indonesia as the research context. The case organisations, particularly the multinational subsidiaries, are dependent on the supply of external ideas in the configuration process. As similar HR ideas are diffused through different channels within the context of the Indonesian HR field, similarities in HR systems are inevitable. The model illustrates various relationships or links among different organisations, including the human actors inside, who are potentially involved in the configuration process. The relationships between multinational subsidiaries and the headquarters and other subsidiaries within the MNCs are only part of complex relationships. Included are the relationships between organisational actors, their institutional contexts, regulative, normative, and cognitive institutions, within multinational environments. These multiple connectivities are important in understanding the diffusion and adoption of different, sometimes conflicting, ideas from and into different organisations within and across fields which at certain points of time then influence the decisions taken by HR actors in the process of configuring HR systems, particularly within multinational subsidiaries. The study empirically analysed the multiple connectivities that have helped to supply ideas to the actors and thus provide strong empirical support for the model. The model also depicts the central role of HR actors, with the support of their counterparts inside and outside the organisations, in mediating the different pressures or influences in managing the process. Empirical findings across the articles support the role played by actors, although the potential or actual agentic behaviour of actors must be understood in the light of their institutional embeddedness.

Although it has now been strongly supported by empirical evidence, the macro model requires, however, further explanations concerning the detailed micro aspects of the process. This is strongly related to the main research question about how HR actors within firms configure the HR systems. The extended explanation on the microprocess aspects is depicted in Figure 1, which captures the sequence of events in the configuration process.

Reconstructing the relationships among key themes generated and used in this research in the micromodel, the configuration of HR systems is understood not as a stand-alone activity but as a result of different challenges to corporate identity which are followed by early interactions with new worldviews adopted either at corporate or HR functional level. These antecedents of the reconfiguration process are likely to be stimulated by macro factors through various mechanisms and enter organisational realms through the inter-connectivity of actors, as well as between actors and institutionalised ideas or institutions in general, through various mechanisms already noted in the macro model.

Each organisation has external linking mechanisms that can tap into the knowledge sources that exist in their immediate or extended environment. Some organisations may have better abilities, namely resources or mechanisms, to reach distant sources of ideas. The organisational and field boundaries of organisations that have far-reaching networks can thus be wider than others that only have a narrow network. Since this research shows that organisations tend to mimic other organisations' organisational practices, they are very much dependent on externally supplied ideas. The connectivities with other organisations and to rich ideas-supplying fields are thus important. The case studies reveal the role of consulting firms, academic institutions, multinational parent firms, and HR professional peers as channels supplying HR ideas to the firms. Being located within a fertile and isomorphic field that is abundant in relevant ideas thus is very important for the mimicking organisations and the ability HR actors to tap the stock of knowledge stored or carried by other actors in the connected fields. 
This research, particularly through the case study of CoCement, shows that the adoption of new ideas is not necessarily always directly implemented or enacted into daily routines of HR practices. Companies postpone, or reinterpret and adjust the ideas in the implementation for a number of reasons such as cultural or identity mismatches. Consequently, the configuration process can be divided into two levels as depicted in Figure 1. The model shows that the configuration process reinforces the on-going construction of corporate identity in signalling a new image of companies as better performing firms, particularly in managing their people. For companies such as CoTobacco, it is important to build a strong employee branding through consolidated HR systems. With regard to the general Indonesian HR field, not too many firms have reached the level of such concern over employee branding, but the diffusion of such an understanding could stimulate the adoption of similar way of managing HR systems as it is an isomorphic field.

The combined macro and micro models are thus argued to be a best representation of the configuration process of HR systems according to the events and conditions captured in this research.
This article thus now turns to the implications of these results, but first considers some limitations of the research.

\section{Limitations and Implications for Future Research}

There are a number of implications to be derived from the research findings to stimulate future research. The implications can be grouped into content and methodological aspects. From a content perspective, all the issues that have been presented and discussed present a number of stimulating ideas proposed for future research. In the following paragraphs these ideas are presented as general themes and some are formulated into specific ideas for further investigation.

It has to be acknowledged that the proposed ideas were generated from certain context of research, namely particular multinational subsidiaries operating in Indonesia as a developing country. Research of this kind cannot also be over-generalized into other contexts. Although it is possible to generate ideas that are theoretically sensitive from such a research arrangement, the limitations of this research need to be taken carefully as well.

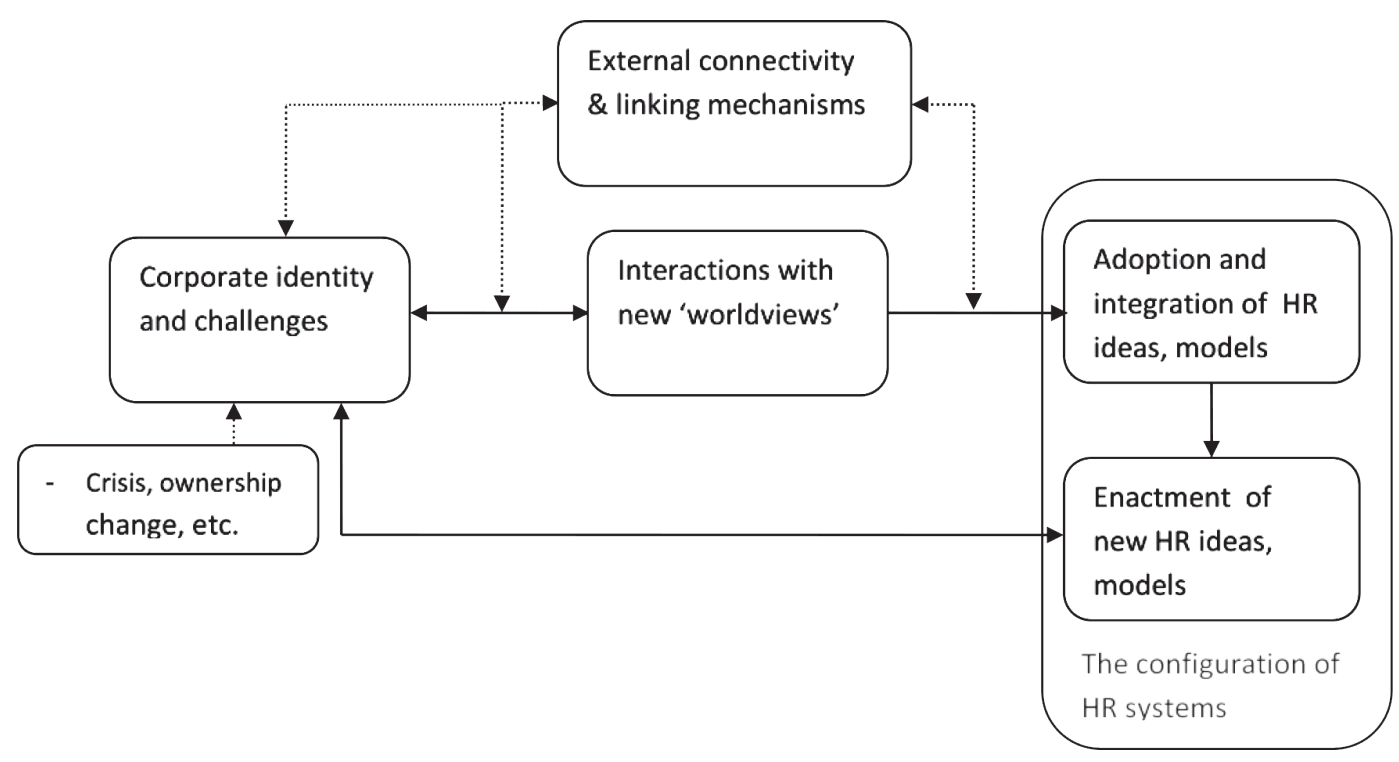

Figure 1. A Micro process model of the configuration of HR systems 
This research has revealed evidence that the institutional context has an influence upon the configuration of HR systems within companies, particularly multinational subsidiaries. The various institutional influences identified in this research, e.g., regulative changes in the Indonesian IR system, increasingly influential professional norms, and the diffusion of new cultural-cognitive frameworks, indicate an evolution of institutional rationalities within the Indonesian HR/IR field. Within the IR system, a previous document of this research has extensively discussed the historical evolution of logics of the system across different governmental regimes in order to understand recent developments within the system (Rupidara \& McGraw 2010). This article thus notes that similar analysis is required in the general HR field, particularly in understanding the evolution of thought both in the academic and professional realms that influences development of the Indonesian HR field. The research has tried to capture some aspects of this development, particularly during the recent past, but a longer timeline analysis could give greater insight into the institutional dynamics of the Indonesian HR field. The results could thus provide a more comprehensive understanding about the configuration process as on-going processes of changes and developments of HR systems (Rupidara \& McGraw 2011). Having also revealed the phenomenon of increased actors' involvement and the emergence of professional HR groups in this research, further study may be worth pursuing.

More specifically, there are a number of research ideas that can stimulate further research. The key themes or variables elaborated in this article can be investigated in future research.

First, in relation to the phenomenon of isomorphism discovered within the HR field of Indonesia, which is likely to be present in other developing countries or even in developed countries that have similar characteristics of an isomorphic field, the research suggests two things at both micro firm level and the wider HR field level as follows:
The higher and the wider the connectivity of a firm to external sources of HR ideas, the more likely it is that a firm will adopt diverse elements of $H R$ systems from its environment.

This idea particularly applies for firms that are seeking multiple external inputs for the (re) configuration of their HR systems. A firm may choose to depend on limited sources of ideas, or even on only one, for example, the multinational headquarters, but the more it opens its 'windows' to external worlds, the more likely it would experience external pressures to conform to existing logics diffused in the field in which it exists. Anticipating the internal political aspects within a firm, the influences may enter the firm through different actors or channels, which could create internal tensions among HR actors within the firm.

Referring to the characteristics of the Indonesian HR field as a highly isomorphic field, it is possible to discover that some organisational fields are more isomorphic than others; the study thus suggests that:

The higher the number of firms, including supporting organisations such as consulting firms, academic institutions, and professional associations, that are involved in the advocacy and diffusion of HR ideas within one field, the more isomorphic is the field.

It should be clearly noted that the number of firms that exist in a field is not always the same as the number of firms involved in the diffusion process, as not all firms reveal their HR knowledge and practices to other firms. The latter type of firms can be categorised as isolated firms within an organisational field. As more firms are expected to be involved, it is likely that multiple similarities will exist across firms as there would also be different sources of ideas and therefore competing models or logics within the field. In such a field, (re) combination of HR ideas or models could be more complicated. Both similarities and differences can co-exist to a greater or lesser extent among firms or groups of firms. Isomorphism is an on-going 
phenomenon. Paying special attention to the Indonesian HR field which is arguably a divided realm (there is a division between elite firms and the majority of small and micro enterprises), a question remains regarding the ability of the field to diffuse the on-going developments in HR ideas far into the lowest levels of firms and other organisations. It is more likely that rather than the whole field, only certain sub-fields are becoming more isomorphic.

Secondly, regarding the relationships between isomorphism, corporate identity, and the configuration of HR systems, three ideas are proposed for investigation.

The more diverse the ideas that are accumulatively adopted and the more constant the configuration process, the more solid the HR systems of a firm become and the firmer the identity of the firm.

This idea indicates that HR systems are a tool used by firms, particularly through HR actors, for corporate identity construction and change. This research has revealed that the adoption of external ideas is central to the configuration process. As stated earlier in the first proposed research idea, the higher the level of exposure one firm has to external sources of ideas, the more diverse the ideas they may adopt. As the ideas become more comprehensive in shaping HR systems of the firm, the systems may become better in both design and implementation. It is argued and empirically supported in the study that changes to HR systems are usually conducted by the actors in reference to better systems of other organisations, in seeking greater legitimacy. The better the systems become, the stronger the legitimacy of the firms, because they are perceived as having similar systems to the high performing, modelled organisations. The stronger the HR systems, the stronger identity of the firm will be.

The micro process model shows that a firm's social identity, a self-categorisation towards a group of other firms, is often an antecedent of the renewal process of many strategic elements of the firm, including its HR systems. This implies that the state of development of the identity can predict the level of recurrence of HR systems (re)configuration. The configuration of HR systems has been described as being dependent upon the supply of external ideas, and it may thus be logically understood that a weaker identity, as perceived by HR actors with reference to the less-developed HR systems of the firm, may stimulate the actors to constantly seek external reinforcement. As argued in this research, an intention to change a firm's identity can stimulate changes in organisational attributes, particularly the HR systems, through mimicking institutionalised ideas from the wider environment. Therefore, it can be proposed that:

The lower the development of a firm's identity, the more likely the firm is to reconfigure its HR systems over time, as it acquires ideas from its institutional environment.

The research also indicates that changes in identity are sometimes predated by an internal crisis or external pressures. In a rapidly changing environment, different and sometimes conflicting principles or logics of organisation exist which put greater pressure on firms to change accordingly. The pressures for change can take a more coercive pattern if a regulatory agency uses its power to impose changes upon the actors. The same can happen for normative power used by professional authorities. Otherwise, changes can more voluntary in an environment where competing logics exist that supply the actors with choices in immediate or far (but connected) institutional fields. Immense changes can be a characteristic of such a field. Within such a turbulent environment, crises can occur within firms where pre-existing logics do not comply with the emerging principles. This can stimulate a change in a firm's identity. Accepting this possibility, another idea to be investigated is:

The higher the level of diffusion of conflicting ideas 
in an organisational field the more likely are firms within the field will feel and experience challenges to their identities and will change their identity according to the higher legitimate reference.

\section{Concluding Remarks}

This article has presented empirical evidence in theorising the process of configuring HR systems within multinational subsidiaries. It has offered a novel perspective on studying HRM in the MNC context, based particularly on the experience of multinational subsidiaries in Indonesia as a developing country and a transitional economy. The novelty offered by this study in the SIHRM field relates to the inclusion of other perspectives into the study, especially the issues of mimesis, the social identity of firms, the connectivity of actors within and outside a defined field, and the widening of the institutional fields.
The research has provided evidence that goes beyond the typical bipolar framework of headquarters-subsidiaries relationships, as the article notes other possible sources of influence facilitated by multiple connectivities of actors and connectivities to globally institutionalised ideas. The article provides a balanced perspective in understanding the complex and difficult tasks in managing multinational subsidiaries, particularly in the configuration of HR systems of multinational subsidiaries. The article has also blended ideas from organisational institutionalism and from the strategic choice and micro politics of actors' perspectives in dealing with the tension of different perspectives that characterise the complexity of the multinational context. The research has therefore achieved its aim, to theorise the process of configuring HR systems. 


\section{REFEREN CES}

Arthur, J. B. (1994). Effects of human resource systems on manufacturing performance and turnover. Academy of Management Journal, 37(3), 670-687.

Arthur, J.B., \& Boyles, T. (2007). Validating the human resource system structure: A levels-based strategic HRM approach. Human Resource Management Review, 17(1): 77-92.

Barney, J. B. (1991). Firm resources and sustained competitive advantage. Journal of Management, 17 (1), $99-120$.

Becker, B., \& Huselid, M. (1998). High performance work systems and firm performance: A synthesis of research and managerial implications. Research in Personnel and Human Resources Management, 16, 53-101.

Bjorkman, I., \& Lu, Y. (2001). Institutionalization and bargaining power explanations in international joint ventures: The case of Chinese - western joint ventures. Organization Studies, 22(3), 491-512.

Bjorkman, I., \& Xiucheng, F. (2002). Human resource management and the performance of western firms in China. International Journal of Human Resource Management, 13(6), 853-864.

Boxall, P. \& Steeneveld, M. (1999). Human resource strategy and competitive advantage: A longitudinal study of engineering consultancies. Journal of Management Studies, 36(4), 443-464.

Burrel, G., \& Morgan, G. (1979). Sociological paradigms and organizational analysis. London: Heinemann.

Chadwick, C., \& Capelli, P. (1999). Alternative to generic strategy typologies in SHRM. Research in Personnel and Human Resource Management, Supplement 4, 1-29.

Charmaz, K. 2006. Constructing grounded theory: A practical guide through qualitative analysis. London: Sage.

Collis, J., \& Hussey, R. (2009). Business research: A practical guide for undergraduate \& postgraduate students. Hampshire: Palgrave Macmillan.

Dahlberg, K., Drew, N., \& Nystrom, M. 2001. Reflective lifeworld research. Lund: Studentlitteratur.

Delery, J. E., \& Doty, D. H. (1996). Modes of theorizing in strategic human resource management: Tests of universalistic, contingency, and configuration. Performance predictions. Academy of Management Journal, 39(4), 802-835.

Den Hartog, D.N., \& Verburg, R.M. (2004). High performance work systems, organisational culture and firm effectiveness. Human Resource Management Journal, 14(1), 55-78.

Denzin, N.K., \& Lincoln, Y.S. (2005). Introduction: The discipline and practice of qualitative research. In Denzin, N.K. and Lincoln, Y.S. The Sage handbook of qualitative research, pp. 1-32. London: Sage.

Edwards, P., \& Wright, M. (2001). High-involvement work systems and performance outcomes: The strength of variable, contingent and context-bound relationships. International Journal of Human Resource Management, 12(4), 568-585.

Eisenhardt, K. M. (1989). Building theories from case study research. The Academy of Management Review, 14 (4), $532-550$.

Elliott, J. (2005). Using narrative in social research: qualitative and quantitative approaches. London: Sage.

Erlandson, D.A., Harris, E.L., Skipper, B.L., \& Allen, S.D. (1993). Doing naturalistic inquiry: A guide to methods. Newbury Park: Sage.

Farley, J. U., Hoenig, S., \& Yang, J. Z. (2004). Key factors influencing HRM practices of overseas subsidiaries in China's transition economy. International Journal of Human Resource Management, 15(4/5), 688-704.

Ferner, A. (1997). Country of origin effects and human resource management in multinational companies. Human Resource Management Journal, 7(1), 19-37.

Guthrie, J. P. (2001). High-involvement work practices, turnover, and productivity: Evidence from New Zealand. Academy of Management Journal, 44(1),180-90.

Huselid, M.A. (1995). The impact of human resource management practices on turnover, productivity, and corporate financial performance. Academy of Management Journal, 38, 635-672.

Jiang, K., Lepak, D. P., Han, K., Hong, Y., Kim, A., \& Winkler, A. L. (2012). Clarifying the construct of human resource systems: Relating human resource management to employee performance. Human resource management review, 22(2), 73-85.

Jovchelovitch, S. \& Bauer, M. W. (2000). Narrative interviewing [online]. London: LSE Research Online. Available at http:// eprints.lse.ac.uk/2633.

Kepes, S., \& Delery, J. (2007). HRM systems and the problem of internal fit. In P. Boxall, J. Purcell \& P. Wright (Eds.). The Oxford handbook of human resource management, pp. 385-404. Oxford: Oxford University Press.

Khatri, N. (2000). Managing Human Resources for Competitive Advantage: A Study of Companies in Singapore. International Journal of Human Resource Management, 11, 336-366.

Lewin, D. (2001). Low involvement work practices and business performance. Proceedings of the 53rd Annual Meeting of Industrial Relations Research Association, 275-292. New Orleans, LA. Downloaded on 1 December 2011 from http:// www.anderson.ucla.edu/documents/ areas/fac/hrob/low-involvement.pdf,

Lewin, D. (2002). HRM and business performance research: Empiricism in search of theory. Paper presented to the 62nd Academy of Management meeting, Denver, CO., 32 pp. 
Li, J. (2003). Strategic Human Resource Management and MNE's Performance in China. International Journal of Human Resource Management, 14, 157-173.

Mabry, L. (2009). Case study in social research. In P. Alasuutari, L. Bickman, \& J. Brannen. The Sage handbook of social research methods, pp. 214-227. London: Sage.

MacDuffie, J.P. (1995). Human resource bundles and manufacturing performance: Organizational logic and flexible production systems in the world of auto industry. Industrial \& Labor Relations Review, 48(2), 197-221.

Monks, K., Kelly, G., Conway, E., Flood, P., Truss, K., \& Hannon, E. (2013). Understanding how HR systems work: the role of HR philosophy and HR processes. Human Resource Management Journal, 23(4), 379-395.

Napier, N.K., \& Vu, V.T. (1998). International human resource management in developing and transitional economy countries: A breed apart? Human Resource Management Review, 8(1), 39-77.

Ozbilgin, M.F. (2009). From journal ranking to making sense of the world. Academy of Management Learning and Education, $8(1), 113-121$.

Paauwe, J. (2004). HRM and performance: Achieving long-term viability. Oxford: Oxford University Press.

Paul, A.K., \& Anantharaman, R. N. (2003). Impact of people management practices on organizational performance: Analysis of a causal model. International Journal of Human Resource Management, 14, 1246-1266.

Pil, F.K., \& MacDuffie, J.P. (1996). The adoption of high involvement work practices. Industrial Relations, 35(3), 423-455.

Rupidara, N. S. (2011). The Configuration of Human Resource Systems Within Multinational Subsidiaries in Indonesia. Macquarie University, Faculty of Business and Economics, Department of Marketing and Management.

Rupidara, N. S. (2018). Connectivity of Actors and Diffusion of Ideas in HR Systems Configuration Process in Multinational Subsidiaries in Indonesia. International Research Journal of Business Studies, 11(3), 159-177.

Rupidara, N. S., \& Darby, R. (2017). Institutional influences on HRM in the Asian business environment: the case of Indonesia. Journal of Asia Business Studies, 11(3), 262-277.

Rupidara, N. S., \& McGraw, P. (2010). Institutional change, continuity and decoupling in the Indonesian industrial relations system. Journal of Industrial Relations, 52(5), 613-630.

Rupidara, N. S., \& McGraw, P. (2011). The role of actors in configuring HR systems within multinational subsidiaries. Human Resource Management Review, 21 (3), 174-185.

Schwandt, T.A. (1994). Constructivist, interpretivist approach to human inquiry. In N.K. Denzin \& Y.S. Lincoln. Handbook of qualitative research, pp. 118-137. Thousands Oaks, CA: Sage.

Stake, R.E. (1994). Case studies. In N.K. Denzin \& Y.S. Lincoln. Handbook of qualitative research, pp. 236-247. Thousands Oaks, CA: Sage.

Stark, S., \& Torrance, H. (2008). Case study. In B. Somekh \& C. Lewin. Research methods in the social sciences, pp. 33-40. London: Sage.

Wright, P. M., McMahan, G. C., \& McWilliams, A. (1994). Human Resources and sustained competitive advantage: A resourcebased perspective. International Journal of Human Resource Management, 5(2), 301-326.

Yin, R.K. (1989). Case study research: Design and methods. Newbury Park, CA: Sage. 